\title{
Plant Growth and Yield Response of Tillage in Wheat Crop with Rotavator and Subsoiler Combination and No Tillage
}

\author{
Sushil Kumar*, Mukesh Jain, Vijaya Rani, Vinod Kumar, Anil Kumar and Naresh \\ Department of Farm Machinery and Power Engineering, CCS Haryana Agricultural \\ University, Hisar-125004, Haryana, India \\ *Corresponding author
}

\begin{tabular}{|l|}
\hline Ke y w o r d s \\
Tillage, No tillage, \\
Rotavator, \\
Subsoiler, \\
Compaction \\
\hline Article Info \\
\hline $\begin{array}{l}\text { Accepted: } \\
\text { 12 February } 2018 \\
\text { Available Online: } \\
\text { 10 March 2018 }\end{array}$ \\
\hline
\end{tabular}

A B S T R A C T
Following the industrial revolution in the nineteenth century, agricultural machinery and tractors became available for tillage operations. Different types of tillage systems have different tillage depths and capacity to change soil physical properties that affect the crop yield and quality. Important soil physical properties such as bulk density, penetration resistance, water infiltration, hydraulic conductivity and soil compaction are affected by tillage. A study on the effect of various tillage methods on soil compaction was conducted during Rabi season of 2013-14 at village Ladwa, Hisar, Haryana (India). Experiment compared the yield, plant and soil parameters of no tillage and tillage with rotavator + subsoiler. Higher soil resistance was found in zero tillage $\left(\mathrm{T}_{1}\right)$ as compared to treatment rotavator + subsoiler $\left(\mathrm{T}_{2}\right)$. However, the soil resistance increased steadily after 30days after sowing (DAS) and 90 DAS and it almost approached the initial soil resistance level, as it was before tillage after 90 DAS. Higher infiltration rate was found in sub-soiler treatment because of the obvious reason. Better plant establishment have been found in the treatment where sub-soiler has been used due to better moisture availability, increased water infiltration rate and increased root growth. Since, many soil parameters were in favour of the treatment rotavator + sub-soiler $\left(\mathrm{T}_{2}\right)$, significant increase in the yield was also found in treatment rotavator + sub-soiler $\left(\mathrm{T}_{2}\right)$.

\section{Introduction}

The prime necessity of tillage is to prepare the land or the seedbed where the plants can easily grow. Using different types of equipments driven manually or by powered, machines make the soil suitable to place the seeds into the desirable depth. Tilling the fields hinders or slowdown the growth of weeds and improve crops' competition against weeds. Moreover, tillage loosens the compacted layers. People started cultivation in the fertile land close to the river valleys of Nile, Tigris, Euphrates, Yangste and Indus. In the early age it was not possible to till vast area of land to desirable depth by hand tools. Following the industrial revolution in the nineteenth century, agricultural machinery and tractors became available for tillage operations. Different types of tillage systems have different tillage depths and capacity to change soil physical and chemical properties that affect the crop yield and quality (Strudley et al., 2008). Time and frequency of tillage also has significant effect 
on crop production (Stenberg et al., 1997). Important soil physical properties such as bulk density, penetration resistance, water infiltration, hydraulic conductivity and soil compaction are affected by tillage (Hamza and Anderson, 2005).

\section{Materials and Methods}

The study was carried out at farmer's field at village ladwa, Hisar, Haryana (India). Experiment consisted of no tillage $\left(\mathrm{T}_{1}\right)$ and tillage operation with Rotavator + sub soiler $\left(\mathrm{T}_{2}\right)$. Soil parameters like soil resistance and water infiltration rate were calculated. Electronic cone penetrometer (model- 58020 Sensorika Australia) was used to measure soil resistance.

Plant parameters like plant establishment, root growth and yield parameter like no. of grain/panicle, 1000-grain weight, and yield were taken. Plant establishment was determined after 15 and 30 days after sowing (DAS) in both treatments. In each treatment, numbers of plants were counted in an area of one square meter.

Average root growth was determined in all the treatments after 15, 30, and 45 days after sowing. In each treatment, three plants were detached carefully by digging instrument and then the plant with the soil was washed with water and the length of root was measured on a scale.

\section{Results and Discussion}

The results of soil resistance $(\mathrm{kPa})$ at different depth $(\mathrm{mm})$ of soil, before tillage, no tillage and tillage with Rotavator + sub soiler is graphically depicted in Figure 1. Soil resistance in treatment $T_{1}$ (no tillage) was found similar to the soil resistance before any tillage operation. However, significant changes in soil resistance have been recorded after using rotavator + sub soiler $\left(\mathrm{T}_{2}\right)$, upto $250 \mathrm{~mm}$. However, the soil resistance approached the same level as it had been before the tillage after the soil strata where the implement cannot reach.

Kumar et al., (2012) also found higher soil resistance in no tillage as compared to conventional tillage. Elhers et al., (1983) also concluded the similar values of soil resistance for no tillage. Kishor et al., (2013) also observed that most tillage practices have pronounced effects on soil hydraulic properties, infiltration rates, percolation, leaching, and oxygen diffusion rate immediately following non-tillage application, but these effects can diminish rapidly.

Water infiltration rate as shown in the Table 1 was higher in treatment $\left(\mathrm{T}_{2}\right)$ as compared to treatment $\mathrm{T}_{1}$. Younesi Alamounti et al., (2007) also found that water infiltration increased with deep tillage.

In $\mathrm{T}_{1}$ at $15 \mathrm{DAS}$, no. of plants $/ \mathrm{m}^{2}$ area was 235 plants, and at 30 DAS it was 268 plants $/ \mathrm{m}^{2}$ areas, and in $\mathrm{T}_{2}$ at $15 \mathrm{DAS}$, no. of plants $/ \mathrm{m}^{2}$ area was 261 plants and at 30 DAS it was 275 plants $/ \mathrm{m}^{2}$ areas. Higher plant population was found in treatment $T_{2}$ as shown in Table 2. Chen et al., (2005) also found that sub soiling promoted much faster crop emergence, higher plant populations.

Higher root growth has been registered in treatment $\mathrm{T}_{2}$ which was $86.7 \mathrm{~cm}, 87.8 \mathrm{~cm}$ and 87.3 as compared to treatment $\mathrm{T}_{1}$ which was $86.5 \mathrm{~cm}, 87.5 \mathrm{~cm}$ and $87 \mathrm{~cm}$ at respective stages (15 DAS, 30 DAS AND 60 DAS) as shown in Table 2. Hongguang et al., (2014) also found similar results that subsoil tillage promoted root development, increased nutrient accumulation, and increased yield. Gajrai et al., (2017) also found that soil related constraints on root growth may be alleviated through deep tillage. 
Table.1 Water infiltration rate $(\mathrm{cm} /$ minute) before and after tillage operation

\begin{tabular}{|c|c|c|}
\hline \multicolumn{2}{|c|}{ Water Infiltration Rate $\left(\mathrm{cm} / \mathrm{min}^{2} \mathrm{inte}\right)$} & \\
\hline Treatment & Before & After \\
\hline No tillage $\left(\mathrm{T}_{1}\right)$ & 1.13 & 1.19 \\
\hline Rotavator + sub soiler $\left(\mathrm{T}_{2}\right)$ & 1.13 & 2.67 \\
\hline
\end{tabular}

Table.2 Plant Parameters at different stages after sowing

\begin{tabular}{|c|c|c|c|c|c|}
\hline \multicolumn{4}{|c|}{ Plant establishment } & \multicolumn{3}{c|}{ Root growth $(\mathrm{cm})$} \\
\hline Treatment & At 15 DAS & At 30DAS & At 15 DAS & At 30 DAS & At 60 DAS \\
\hline No tillage $\left(\mathrm{T}_{1}\right)$ & 235 & 268 & 86.5 & 87.5 & 87 \\
\hline Rotavator + & 261 & 275 & 86.7 & 87.8 & 87.3 \\
\hline sulb soiler $\left(\mathrm{T}_{2}\right)$ & & & & & \\
\hline
\end{tabular}

\section{Table.3 Yield attributes of both treatments}

\begin{tabular}{|c|c|c|c|}
\hline \multicolumn{4}{|c|}{ Yield A tributes } \\
\hline Treatment & $\begin{array}{l}\text { No. of Grains/ Ear } \\
\text { Head }\end{array}$ & $\begin{array}{l}1000 \text { Grain Weight } \\
(\mathrm{g})\end{array}$ & Yield (q/ha) \\
\hline No tillage $\left(\mathrm{T}_{1}\right)$ & 60 & 38.90 & 58.87 \\
\hline $\begin{array}{c}\text { Rotavator }+ \text { sub } \\
\text { soiler }\left(\mathrm{T}_{2}\right)\end{array}$ & 62 & 38.97 & 61.23 \\
\hline
\end{tabular}

Fig.1 Soil resistance $(\mathrm{kPa})$ at different depth $(\mathrm{mm})$ of soil before tillage, no tillage $\left(\mathrm{T}_{1}\right)$ and tillage with rotavator + sub soiler $\left(\mathrm{T}_{2}\right)$

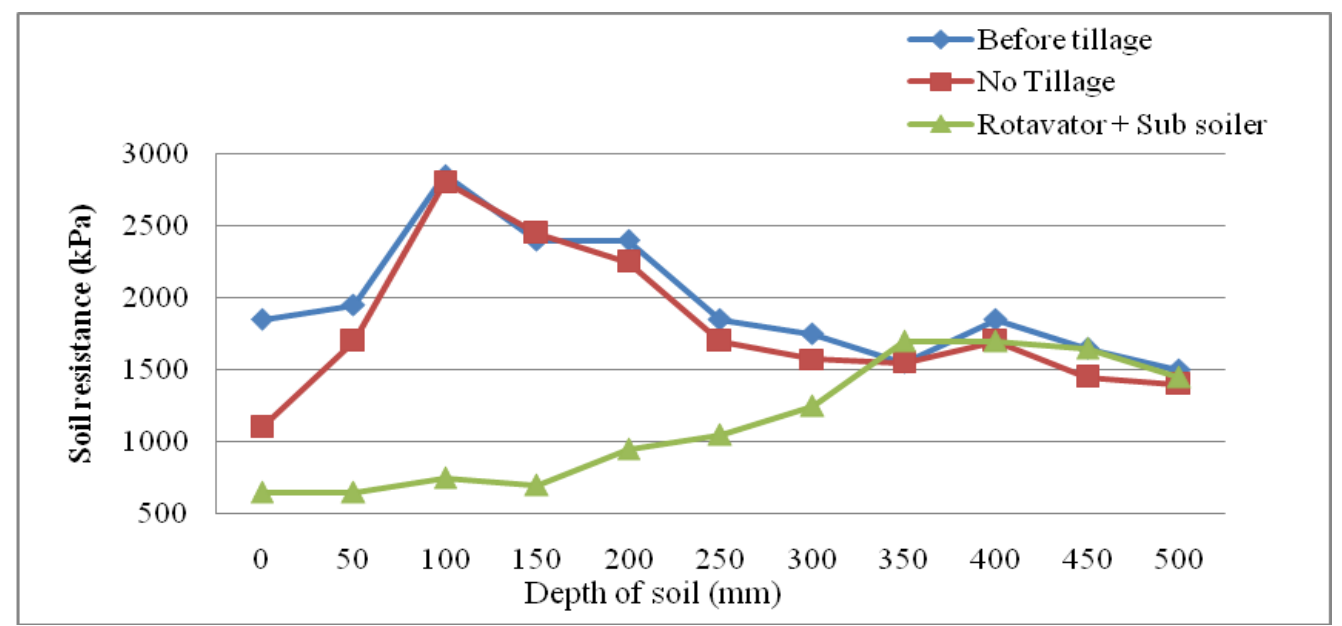

Maximum numbers of grains/ear-head were found in treatment rotavator + sub-soiler $\left(\mathrm{T}_{2}\right)$ which was 62due to existence of favorable conditions in this treatment. It was found that maximum 1000 grain weight was in treatment rotavator + sub-soiler $\left(\mathrm{T}_{2}\right)$ because of maximum favorable conditions such as higher pulverization index, higher water infiltration rate and higher root growth which resulted in higher nutrient uptake (Table 3).

Maximum yield was found in treatment $T_{2}$, reason being comparatively higher root growth, higher 1000 grain weight, higher plant 
population and also higher water infiltration due to use of sub-soiler. Gangwar et al., (2004) also found that among different tillage levels, conventional tillage recorded the highest mean yield of wheat.

The soil cone index varies with soil depth profile. Lower soil CI values are associated with a tilled layer near the soil surface, while higher CI values are associated with a compact soil layer below the tilled layer. The soil compaction level almost approached the initial values as it was before tillage operation after 90 days of sowing. Higher water infiltration after deep tillage. Tillage with rotavator and subsoiler influence the root growth of wheat crop and thus increases the root length. Significantly, higher yield was produced using rotavator + subsoiler as compared to no tillage.

\section{References}

Chen, Y., Cavers, C., Tessier, S., Monero, F., and Lobb, D. 2005. Short-term tillage effects on soil cone index and plant development in a poorly drained, heavy clay soil. Soil \& Tillage Research. 82: 161-171.

Ehlers, W., Kopke, U., Hesse, F., and Bohm, W. 1983. Penetration resistance and root growth of oats in tilled and untilled loess soil. Soil \& Tillage Research.3: 261-275.

Gajrai, P.R., Parihar, S.S., Cheema, H.S., and Kapoor, A. 2017. Irrigation and tillage effect on root development, water use and yield of wheat on coarse textured soils. Irrigation Science. 12(3): 161-168.

Gangwar, K.S., Singh, K.K. and Sharma, S.K. 2004. Effect of tillage on growth, yield and uptake in heat after rice in the Indo-
Gangetic Plains of India. The Journal of Agricultural Sciences. 142(4): 453-459

Hamza, M.A., and Anderson, W.K. 2005. Soil compaction in cropping systems: A review of the nature, causes and possible solutions. Soil \& Tillage Research. 82: 121-145.

Hongguang, Cai., Wei, Ma., Xiuzhi, Zhang., Jieqing, Ping., Xiaogong, Yan., Jianzhao, Liu., Jingchao Yuan., Lichun, Wang., and Jun, Ren. 2014. Effect of subsoil tillage depth on nutrient accumulation, root distribution, and grain yield in spring maize. The Crop Journal. 2:297-307.

Kishor, P., Ghosh, A.K., and Claramma, P.V. 2013. Influence of tillage on soil physical environment. International Journal of Agronomy and plant production. 4(10): 2592-2597.

Kumar, A., Chen, Y., Sadek, A. and Rahman, S., 2012. Soil cone index in relation to soil texture, moisture content and bulk density for no tillage and conventional tillage. The CIGR Journal. 14(1): 26-37.

Stenberg, M., Aronsson, H., Linden, B., Rydberg, T., and Gustafson, A. 1997. Nitrogen leaching in different tillage systems. Proc. 14th ISTRO Conference, 27 July, 1 August, Puoawy, Poland, Bibliotheca Fragmenta Agronomica. 2B/97: 605-608.

Strudley, M.W., and Green, T.R. 2008. Tillage effect on soil hydraulic properties in space and time: State of the science. Soil and Tillage research. 99(1): 4-48.

Younesi, A.M., and Navabzadeh, M. 2007. Investigation of plowing depth effect on some soil physical properties. Pakistan Journal of Biological Sciences. 10(24): 4510-4514.

\section{How to cite this article:}

Sushil Kumar, Mukesh Jain, Vijaya Rani, Vinod Kumar, Anil Kumar and Naresh. 2018. Plant Growth and Yield Response of Tillage in Wheat Crop with Rotavator and Subsoiler Combination and No Tillage. Int.J.Curr.Microbiol.App.Sci. 7(03): 1597-1600.

doi: https://doi.org/10.20546/ijcmas.2018.703.192 